\title{
Daerah Penangkapan Potensial Tuna Madidihang Thunnus albacares, Bonnaterre, 1788 (Teleostei:Scombridae) di Laut Seram
}

\author{
Jacobus Bunga Paillin*, Delly Dominggas Paulina Matrutty, Stany Rachel Siahainenia, \\ Ruslan Husen Saban Tawari, Haruna dan Putri Talahatu \\ Jurusan Pemanfaatan Sumberdaya Perikanan, Fakultas Perikanan dan Ilmu Kelautan, \\ Universitas Pattimura \\ Jl. Mr. Chr. Soplanit Kampus Poka, Ambon Maluku 97234 Indonesia \\ Email: bobby.b.paillin@gmail.com
}

\section{Abstract \\ Potential Fishing Ground of Thunnus albacares Bonnaterre, 1788 (Teleostei:Scombridae) in Seram Sea}

\begin{abstract}
This research aims are to determine the potential fishing grounds of yellowfin tuna based on the approach of sea surface temperature, chlorophyll-a and catches in the Ceram Sea. Overall catches of 407 Individuals. In January the total catches were 66 individuals (14.44\%), in February 67 individuals (14.66\%), in March 84 individuals (18.38\%), in April 116 individuals (25.38\%) and in May 124 individuals (27.13\%). The distribution of sea surface temperature and chlorophyll-a in the Ceram Sea in January-May 2019 looks varied. In January the average sea surface temperature was $29.13^{\circ} \mathrm{C}$, in February sea surface temperature was $29.54^{\circ} \mathrm{C}$, in March sea surface temperature was $30.12^{\circ} \mathrm{C}$, in April sea surface temperature was $30.12^{\circ} \mathrm{C}$, in May sea surface temperature was $29.77^{\circ} \mathrm{C}$. Chlorophyll-a concentration in January and February was $0.21 \mathrm{mg} / \mathrm{m}^{3}$, March was $0.20 \mathrm{mg} / \mathrm{m}^{3}$, April was $0.16 \mathrm{mg} / \mathrm{m}^{3}$, and May was $0.25 \mathrm{mg} / \mathrm{m}^{3}$. The results of the t-test analysis showed the $P$-value of sea surface temperature was $0.009<0.05$, chlorophyll-a P-value $0.00048<0.05$. Determination of potential fishing areas based on sea surface temperature, chlorophyll-a, and CPUE indicators shows that potential fishing areas are found in January, February, March, and May, while in April are in the medium potential category.
\end{abstract}

Keywords: Chlorophyl-a, CPUE, Sea Surface Temperature

\begin{abstract}
Abstrak
Penelitian ini dilaksanakan dengan tujuan menentukan daerah penangkapan potensial Tuna madidihang berdasarkan pendekatan suhu permukaan laut, klorofil-a dan hasil tangkapan di Laut Seram. Secara keseluruhan hasil tangkapan ikan tuna madidihang sebanyak 407 Individu. Bulan Januari total hasil tangkapan sebanyak 66 individu (14.44\%), bulan Februari 67 individu (14.66\%), bulan Maret 84 individu (18.38\%), bulan April 116 individu (25.38\%) dan bulan Mei 124 individu (27.13\%). Sebaran suhu permukaan laut dan klorofil-a di Laut Seram pada bulan JanuariMei 2019 terlihat bervariasi. Bulan Januari rata-rata suhu permukaan laut sebesar $29.13^{\circ} \mathrm{C}$, bulan Februari suhu permukaan laut $29.54 \circ$, bulan Maret suhu permukaan laut $30.12^{\circ} \mathrm{C}$, bulan April suhu permukaan laut $30.12^{\circ} \mathrm{C}$, bulan Mei suhu permukaan laut $29.77^{\circ} \mathrm{C}$. Konsentrasi klorofil-a pada bulan Januari dan Februari sebesar $0.21 \mathrm{mg} / \mathrm{m}^{3}$, bulan Maret sebesar $0.20 \mathrm{mg} / \mathrm{m}^{3}$, bulan April sebesar $0.16 \mathrm{mg} / \mathrm{m}^{3}$, dan bulan Mei sebesar $0.25 \mathrm{mg} / \mathrm{m}^{3}$. Hasil analisis uji t menunjukan nilai P-value suhu permukaan laut sebesar 0,009<0,05, klorofil-a P-value 0,00048<0,05. Penentuan daerah penangkapan ikan potensial berdasarkan indikator suhu permukaan laut, klorofil-a dan CPUE menunjukkan daerah penangkapan ikan potensial terdapat pada bulan Januari, Februari, Maret, dan Mei, sedangkan pada bulan April berada dalam kategori potensial sedang.
\end{abstract}

Kata Kunci: Klorofil-a, CPUE, Suhu Permukaan Laut 


\section{PENDAHULUAN}

Laut Seram adalah wilayah perairan yang berada di Provinsi Maluku yang merupakan habitat hidup bagi berbagai jenis ikan baik yang bersifat ekonomis maupun bersifat komersil salah satunya adalah ikan Tuna Madidihang (Thunnus albacares). Ikan Tuna Madidihang diperkirakan sangat melimpah di perairan ini karena merupakan jalur ruaya bagi ikan tersebut menuju ke wilayah perairan lainnya. Sebagai jalur ruaya ikan tuna maka perairan Laut Seram selama ini dijadikan daerah penangkapan ikan (DPI) oleh nelayan skala kecil maupun skala besar. Nelayan skala kecil yang biasanya melakukan aktivitas penangkapan ikan tuna di Laut Seram adalah nelayan yang berasal dari Desa Kawa Kabupaten Seram Bagian Barat Provinsi Maluku. Aktivitas penangkapan dilakukan sepanjang tahun dengan mengikuti arah pergerakan ikan lumbalumba atau adanya bongkahan kayu yang mengapung di laut. Hal ini menyebabkan penangkapan ikan oleh nelayan tidak efektif dan efisien karena banyaknya waktu dan biaya terbuang untuk mengejar sekelompok ikan serta tingginya biaya operasional (Shabrina et al., 2017).

Berbagai cara telah dilakukan untuk meminimalisir biaya operasional penangkapan ikan yang tinggi oleh nelayan, salah satunya dengan menggunakan teknologi penginderaan jauh melalui pendekatan suhu permukaan laut (SPL) dan Klorofil-a. Akan tetapi hasilnya belum memberikan informasi secara specifik akibat dinamika perairan yang selalu berubah-ubah dan berbeda antara suatu perairan dengan perairan lainnya karena letak geografis wilayah. Hasil penelitian Ekayan et al. (2017) di Perairan Selata Jawa-Bali mendapatkan bahwa SLP tidak berpengaruh langsung terhadap hasil tangkapan karena suhu perairan yang selalu berubah-ubah dan fluktuatif. Demikian juga tinggi atau rendahnya klorofil-a tidak memberikan pengaruh signifikan terhadap hasil tangkapan. Umar et al. (2015) juga menyatakan bahwa klorofil-a tidak berpengaruh langsung terhadap hasil tangkapan ikan tuna. Sedangkan Yunus et al. (2019) menyatakan, bahwa klorofil-a paling berpengaruh terhadap hasil tangkapan ikan tongkol (Euthynnus sp) di Selat Makasar.

Dalam hubungannya dengan pendugaan daerah penangkapan ikan (DPI) maupun zona potensial penangkapan tuna dari beberapa hasil penelitian sebelumnya pada wilayah lain di Indonesia, yang dianalisis dengan menggunakan parameter oseanografi, baik berbasis data citra maupun data insitu yang dihubungkan dengan data produksi statistik perikanan (Siregar et al., 2018; Yunus et al., 2019), juga berbagai penelitian yang telah dilakukan di Laut Banda, Laut Maluku, Laut Seram dan Sekitarnya (Wagiyo et al., 2015; Rochmady, 2015; Tangke et al., 2016: 2017, Bafagi et al., 2017 ), hasilnya masih dalam skala luas, tidak spesifik dan lebih bersifat eksploratif. Dengan demikian perlu dilakukan kajian yang didasarkan pada kombinasi antara data lapangan dengan data citra satelit, yang dikemas dalam sebuah sistem informasi geografis (SIG) sehingga penentuan daerah penangkapan potensial ikan tuna madidihang diharapkan signifikan dan lebih spesifik dalam menjawab kebutuhan nelayan tuna di Laut Seram terkait pemilihan DPI potensial maupun waktu penangkapan. Tujuan penelitian ini yaitu: menentukan daerah penangkapan potensial Tuna madidihang berdasarkan suhu permukaan laut, klorofil-a dan hasil tangkapan nelayah tuna madidihang selama Januari-Mei 2019 di Laut Seram.

\section{MATERI DAN METODE}

Penelitian ini dilakukan pada bulan Januari - Mei 2019 di perairan Laut Seram dengan fishing base di Desa Kawa Kabupaten Seram Bagian Barat (Gambar 1). Pengambilan data jumlah dan ukuran hasil tangkapan ikan tuna madidihang serta titiktitik penangkapan ikan dilakukan dengan mengikuti langsung operasional penangkapan ikan. Ikan tuna yang tertangkap pada daerah penangkapan dicatat jumlah dan ukurannya kemudian diambil posisinya dengan menggunakan GPSmap 62s Garmin, sedangkan data citra satelit berupa suhu permukaan laut (SPL) maupun Klorofil-a di unduh dari situs www.oceancolor.dsfc. nasa.gov. Data hasil tangkapan maupun 


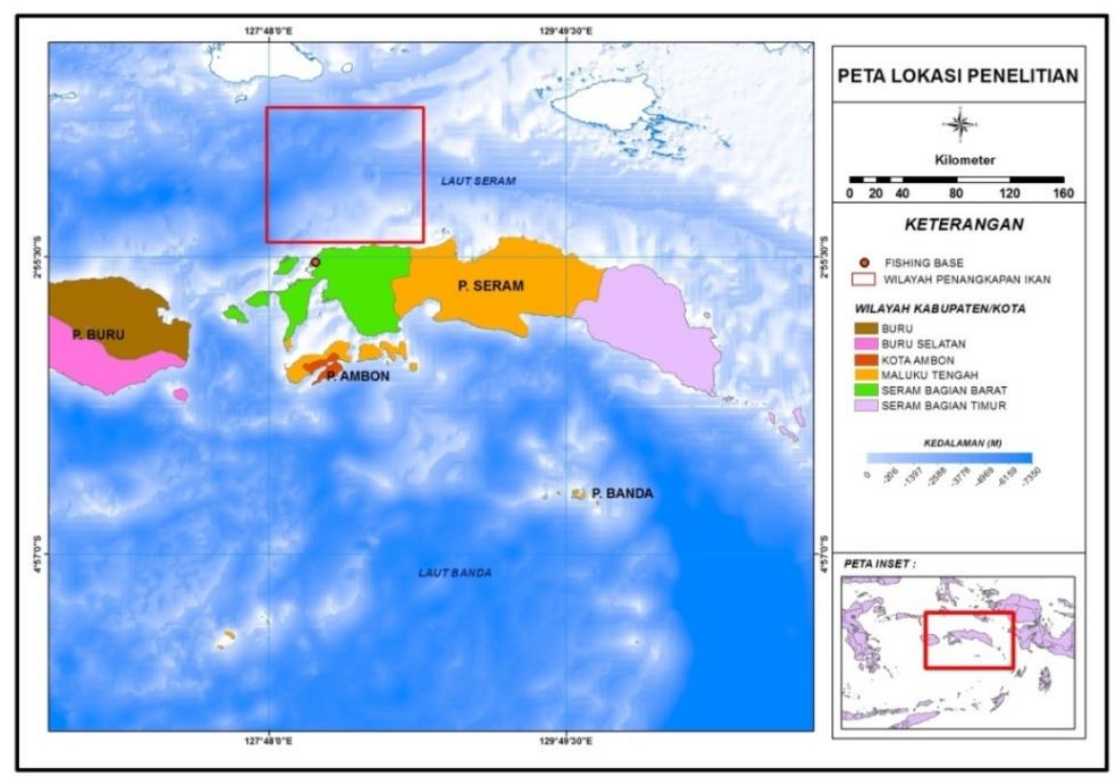

Gambar 1. Peta Lokasi Penelitian

data citra satelit tersebut kemudian diolah, dianalisis dan dipetakan. Penentuan daerah penangkapan potensial tuna madidihang ini didasarkan pada 3 indikator penilaian yaitu jumlah hasil tangkapan (CPUE), suhu permukaan laut optimum penangkapan ikan dan klorofil-a dari tiap-tiap titik penangkapan ikan.

Penilaian DPI potensial berdasarkan kriteria CPUE penting dilakukan untuk menjaga ketersediaan stok sumberdaya Ikan dalam jangka panjang. ukuran ikan tuna madidihang yang dikatakan layak tangkap adalah ikan tuna yang memiliki bobot $\geq 20 \mathrm{~kg}$ karena ukuran tersebut merupakan ukuran yang pernah memijah sekali. Kriteria penilaian DPI potensial berdasarkan CPUE disajikan pada Tabel 1.

Suhu di suatu perairan merupakan faktor penting bagi kehidupan organisme, baik dalam aktivitas metabolisme dan menentukan keberadaan serta penyebaran ikan. Jika suatu perairan dengan penyebaran suhu permukaan laut optimum antara $29{ }^{\circ} \mathrm{C}-30^{\circ} \mathrm{C}$, maka daerah penangkapan ikan tersebut dikategorikan potensial. Jika suatu perairan dengan Suhu permukaan laut tidak optimum $<29^{\circ} \mathrm{C}$ dikategorikan kurang potensial. Penilaian Daerah penangkapan ikan potensial melalui indikator SPL ditunjukkan pada Tabel 2.
Data klorofil-a hasil deteksi MODIS yang telah diolah menggunakan software SeaDAS juga digunakan sebagai indikator penilaian Daerah penangkapan ikan. Kategori Daerah penangkapan ikan dibagi berdasarkan kandungan klorofil-a nya. Jika suatu perairan dengan kandungan klorofil-a lebih besar dari $0.2 \mathrm{mg} / \mathrm{m}^{3}$, maka Daerah penangkapan ikan tersebut dikategorikan potensial. Jika suatu perairan dengan kandungan klorofil-a $0.1-0.2 \quad \mathrm{mg} / \mathrm{m}^{3}$ dikategorikan sedang dan jika suatu perairan dengan kandungan Klorofil-a kurang dari 0.1 $\mathrm{mg} / \mathrm{m}^{3}$, maka DPI tersebut dikategorikan kurang potensial. Penilaian Daerah penangkapan ikan melalui indikator klorofil-a ditunjukkan pada Tabel 3.

Kandungan klorofil-a dapat digunakan sebagai ukuran banyaknya fitoplankton pada suatu perairan tertentu dan dapat digunakan sebagai petunjuk produktivitas perairan. Konsentrasi klorofil-a yang lebih besar dari $0.2 \mathrm{mg} / \mathrm{m}^{3}$ telah menunjukkan kehadiran fitoplankton yang memadai untuk menopang atau mempertahankan kelangsungan hidup perkembangbiakan perikanan.

\section{HASIL DAN PEMBAHASAN}

Produksi Tuna Madidihang pada bulan Januari sampai Mei 2019 di Laut Seram berbeda-beda untuk setiap bulan, baik 
jumlah maupun bobot hasil tangkapan. Jumlah hasil tangkapan cenderung mengalami peningkatan sementara bobot hasil tangkapan mengalami fluktuasi setiap bulan. Bobot hasil tangkapan dapat diketahui dengan nilai Catch per Unit Effort (CPUE). Jumlah dan CPUE Tuna Madidihang diperlihatkan pada Gambar 2.

Jumlah hasil tangkapan ikan tuna madidihang secara keseluruhan sebanyak 407 Individu. Pada bulan Januari total hasil tangkapan sebanyak 66 individu (14.44\%), bulan Februari sebanyak 67 individu (14.66\%), bulan Maret sebanyak 84 individu (18.38\%), bulan April sebanyak 116 individu (25.38\%) dan bulan Mei sebanyak 124 individu (27.13\%). Rendahnya jumlah hasil tangkapan pada bulan Januari dan Februari disebabkan intensitas penangkapan ikan berkurang, jumlah nelayan yang melaut juga sedikit karena kondisi perairan Laut Seram bergelombang disaat musim barat. Sedangkan pada bulan Maret, April, dan Mei merupakan musim peralihan dimana kondisi perairan Laut Seram mulai tenang sehingga intensitas penangkapan meningkat, nelayan yang melaut dalam jumlah banyak, yang berdampak juga terhadap jumlah hasil tangkapan.

Haruna et al. (2018) menyatakan bahwa kegiatan operasional penangkapan pancing ulur tuna madidihang di Maluku cenderung mengurangi upaya penangkapan karena perubahan cuaca yang sulit diprediksi. Menurut Waileruny dan Matruty (2015) kapal Pancing tonda berukuran kecil untuk menangkap ikan tuna pada Musim Timur dan Musim Barat sangat tidak menguntungkan karena menghadapi hambatan alam seperti angin dan gelomban, bahkan beresiko kecelakaan. Dengan demikian perubahan musim maupun cuaca akan mempengaruhi produktivitas hasil tangkapan, komposisi tangkapan, dan daerah penangkapan (fishing ground).

Berdasarkan bobot hasil tangkapan nelayan per bulan (Gambar 2) dari sejumlah trip penangkapan (CPUE) terlihat bahwa pada bulan Januari CPUE sebesar 29,22 $\mathrm{kg} /$ trip, bulan Februari CPUE sebesar 26,71 $\mathrm{kg} /$ trip, bulan Maret CPUE sebesar 23,83 $\mathrm{kg} /$ trip, bulan April CPUE sebesar 23,44 kg/trip,

Tabel 1. Penilaian DPI berdasarkan indikator CPUE

\begin{tabular}{cccc}
\hline Kategori CPUE & Kriteria & Skor/ Bobot & Kategori DPI \\
\hline Tinggi & CPUE $\geq 20 \mathrm{~kg}$ & 6 & Potensial \\
Rendah & CPUE $<20 \mathrm{~kg}$ & 3 & Kurang Potensial \\
\hline
\end{tabular}

Sumber: FAO, 2016, modifikasi

Tabel 2. Penilaian Daerah penangkapan ikan berdasarkan indikator Suhu Permukaan Laut

\begin{tabular}{cccc}
\hline Kategori SPL & Kriteria & Skor/ Bobot & Kategori DPI \\
\hline Optimum & $29{ }^{\circ} \mathrm{C}-30^{\circ} \mathrm{C}$ & 6 & Potensial \\
Tidak optimum & $<29{ }^{\circ} \mathrm{C}$ & 2 & Kurang Potensial \\
\hline
\end{tabular}

Survey lapangan, 2019

Tabel 3. Penilaian Daerah penangkapan ikan berdasarkan indikator Klorofil-a

\begin{tabular}{cccc}
\hline Kategori Klorofil-a & Kriteria & Skor/ Bobot & Kategori DPI \\
\hline Banyak & $>0.2 \mathrm{mg} / \mathrm{m}^{3}$ & 6 & Potensial \\
Sedang & $0.1 \mathrm{mg} / \mathrm{m}^{3}-0.2$ & 4 & Sedang \\
Sedikit & $<0.1 \mathrm{mg} / \mathrm{m}^{3}$ & 2 & Kurang potensial \\
\hline
\end{tabular}

Sumber: Widodo, 1999 


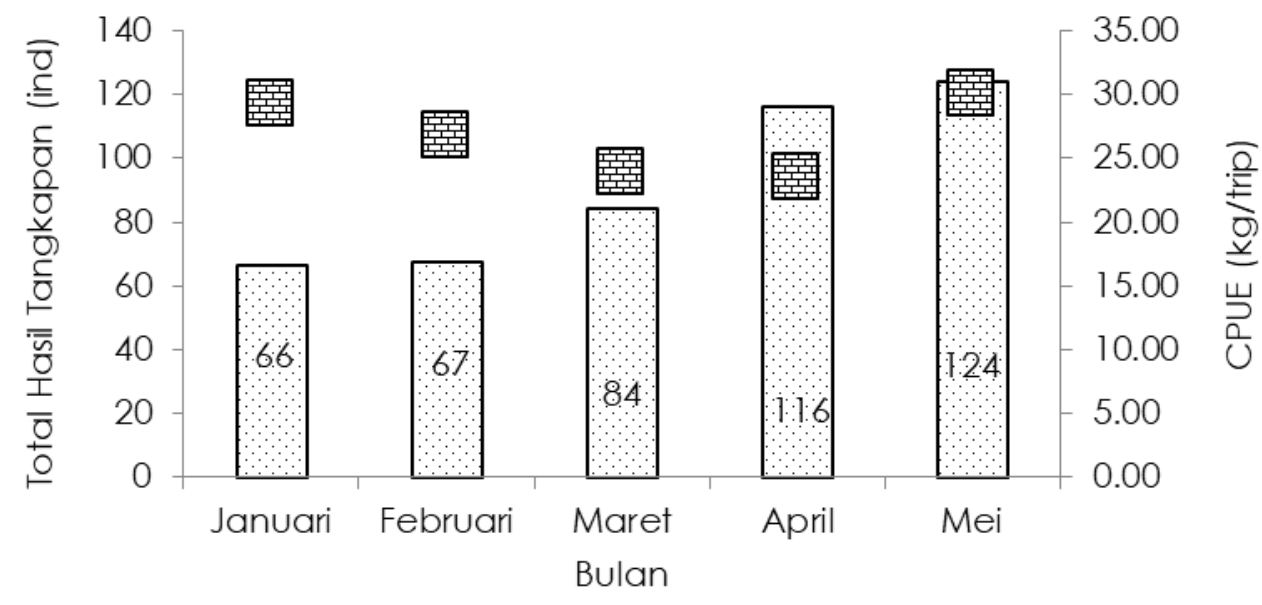

口Hasl Tangkapan (ind) 国CPUE (kg/trip)

Gambar 2. Jumlah dan CPUE Hasil Tangkapan Ikan Tuna Madidihang pada Bulan Januari-Mei 2019

sedangkan pada bulan Mei CPUE sebesar 29,99 kg/trip. Hasil tersebut menunjukan bahwa CPUE tertinggi terdapat pada bulan Mei, Januari dan bulan Februari, sedangkan CPUE terendah pada bulan Maret, dan April.

Pada bulan Januari dan Februari CPUE tinggi, sementara jumlah hasil tangkapan sedikit disebabkan bobot individu ikan tuna yang tertangkap lebih besar sehingga mengakibatkan CPUE meningkat, sebaliknya pada bulan Maret dan April CPUE rendah, namun jumlah hasil tangkapan lebih banyak dikarenakan bobot dari tiap individu ikan yang tertangkap berukuran kecil sehingga mengakibatkan CPUE rendah.

Pemanfaatan data citra satelit yakni suhu permukaan laut dan klorofil-a sangatlah penting karena telah membuktikan suatu wilayah penangkapan ikan yang produktif (Zainudin et al., 2006). Menurut Ekayana, et al. (2017) sebaran suhu permukaan laut dipengaruhi oleh jumlah bahang yang diterima dari pancaran sinar matahari, dimana wilayah perairan yang menerima pancaran sinar matahari paling banyak adalah wilayah perairan yang dekat dengan lintang $0^{\circ}$ dan nantinya berpengaruh terhadap kehidupan klorofil-a di perairan. Lebih lanjut Allain et al. (2005) menyatakan bahwa parameter oseanografi perairan seperti suhu permukaan laut, klorofil-a, kadar oksigen dan kedalaman turut mempengaruhi sebaran ikan tuna secara horisontal maupun vertikal. Sebaran suhu permukaan laut (SPL) dan klorofil-a di laut Seram (Gambar 3) menunjukkan bahwa sebaran suhu permukaan laut (SPL) di Laut Seram pada bulan Januari-Mei 2019 berkisar antara 28,41 ${ }^{\circ} \mathrm{C}-30,63{ }^{\circ} \mathrm{C}$ dengan rata-rata suhu permukaan laut sebesar 29,93 ०C. Suhu optimum penangkapan ikan tuna madidihang berkisar antara $29-30^{\circ} \mathrm{C}$. Kondisi ini menunjukkan bahwa suhu permukaan laut di Laut Seram pada bulan Januari-Mei 2019 merupakan suhu perairan yang hangat.

Suhu perairan yang hangat sangat disukai oleh ikan tuna dan merupakan predator yang selalu berada di lapisan permukaan pada siang hari untuk berburu mangsanya (Gradieff, 2003 dalam Bahri et al., 2017). Menurut Leavastu dan Hela (1970) tuna madidihang merupakan jenis ikan pelagis besar yang beruaya sedikit di atas lapisan termoklin pada siang hari dan akan bervaya ke lapisan permukaan pada sore hari. Lebih lanjut FAO (2003) dalam Bahri et al. (2017) menyatakan bahwa suhu perairan 18$31{ }^{\circ} \mathrm{C}$ disukai oleh ikan tuna madidihang, dengan demikian suhu perairan yang ada di Laut Seram masih berada dalam kisaran suhu yang di sukai oleh ikan tuna madidihang. Konsentrasi klorofil-a pada bulan Januari-Mei 2019 terlihat berfluktuasi (Gambar 3). 
Sebaran klorofil-a di Laut Seram berkisar antara $0,12-0,35 \mathrm{mg} / \mathrm{m}^{3}$ dengan rata-rata konsentrasi klorofil-a $0,19 \mathrm{mg} / \mathrm{m}^{3}$, sedangkan klorofil-a optimum penangkapan ikan berkisar antara $0,1-0,3 \mathrm{mg} / \mathrm{m}^{3}$. Abigail et a.l (2015) menyatakan bahwa sebaran klorofil-a di suatu perairan sangat bervariasi karena tergantung dari intensitas cahaya matahari, dimana intensitas cahaya matahari yang tinggi akan mengakibatkan tingkat fotosintesis meningkat. Selanjutnya Tangke et al. (2015) menyatakan bahwa umumnya tuna madidihang tertangkap pada kisaran klorofil-a 0,1-0,35 mg/m . Simbolon dan Girsang (2009) dalam Prayoga et al. (2017) menyatakan bahwa konsentrasi klorofil-a yang terdapat di suatu perairan tidak secara langsung mempengaruhi ketersediaan ikan yang berada pada wilayah perairan tersebut, akan tetapi ada jarak waktu (time leg) dimana konsentrasi klorofil-a yang terdapat di suatu wilayah perairan terlebih dahulu dimakan oleh organisme zooplankton atau krustasea yang masih berukuran juvenil, dan selanjutnya dimakan dalam tingkatan trofik diatasnya.

Suhu permukaan laut dan klorofil-a merupakan suatu parameter oseanografi yang dapat digunakan sebagai indikator untuk mengetahui keberadaan suatu jenis ikan. Cahya et al. (2016) mengemukakan bahwa suhu permukaan laut dan klorofil-a merupakan faktor yang paling berpengaruh terhadap distibusi ikan, meskipun terdapat beberapa parameter lainnya tergantung kondisi perairan tersebut. Data produksi ikan tuna madidihang dapat dilihat pada Gambar 4.

Pengaruh suhu permukaan laut dan konsentrasi klorofil-a terhadap hasil tangkapan ikan tuna pada bulan Januari-Mei 2019 berbeda-beda. Rata-rata suhu perairan bulanan di Laut Seram berkisar antara 29,13$29,77^{\circ} \mathrm{C}$ dan konsentrasi klorofil-a berkisar antara 0,21-0,25 $\mathrm{mgm}^{3}$, dengan produksi hasil tangkapan (CPUE) rata-rata berkisar antara 23,44-29,77 kg/trip. Hasil tangkapan (CPUE) tertinggi terjadi pada bulan Mei dengan ratarata suhu perairan 29,77 ${ }^{\circ} \mathrm{C}$ dan rata-rata konsentrasi klorofil-a 0,25 mgm3 ${ }^{3}$, diikuti oleh bulan Januari dengan rata-rata suhu perairan 29,13 ${ }^{\circ} \mathrm{C}$ dan rata-rata klorofil-a sebesar 0,21 $\mathrm{mgm}^{3}$. Produksi hasil tangkapan terendah terdapat pada bulan Maret dan April dengan rata-rata kisaran suhu perairan masing-masing sebesar $30,12^{\circ} \mathrm{C}$ dan $30,26^{\circ} \mathrm{C}$ dan kisaran konsentrasi klorofil-a masingmasing sebesar $0,20 \mathrm{mg} / \mathrm{m}^{3}$ dan $0,16 \mathrm{mg} / \mathrm{m}^{3}$. Secara keseluruhan ikan tuna madidihang yang tertangkap pada bulan Januari-Mei 2019 merupakan ikan yang layak tangkap (FAO, 2016). Hasil penelitian Haruna et al. (2018) di Laut Banda menyatakkan bahwa ukuran layak tangkap tuna madidihang 115,2 $\mathrm{cm}$ FL dengan berat rata-rata $20 \mathrm{~kg}$.

Untuk menguji hubungan suhu permukaan laut dan klorofil-a terhadap hasil tangkapan tuna madidihang digunakan metode regresi linear berganda. Dalam analisis ini suhu permukaan laut dan klorofil-a dijadikan sebagai variable bebas (independent) sedangkan hasil tangkapan (CPUE) dijadikan sebagai variable tak bebas (dependent).

Hasil analisis menunjukkan bahwa Fnitung (7.548832) $>$ Ftabel $_{\text {tab }}(0.62815)$ dan nilai $F_{\text {sig }}$ $(0.001411)<0,05$. Hal ini menunjukkan bahwa parameter perairan yaitu suhu permukaan laut dan klorofil-a secara bersama-sama berpengaruh nyata terhadap hasil tangkapan ikan tuna madidihang pada selang kepercayaan 95\%. Nilai R (koefisiesn korelasi) sebesar 0,48916. Ini berarti bahwa hubungan suhu permukaan laut dan klorofil-a terhadap hasil tangkapan (CPUE) tuna madidihang sebesar $48,92 \%$. Koefisien determinasi ( $R$ Square) sebesar 0.23927, ini berarti pengaruh suhu permukaan laut dan klorofil-a terhadap hasil tangkapan sebesar $23,93 \%$.

Dari hasil analisis ini model regresi yang dapat digunakan untuk menjelaskan hubungan antara suhu permukaan laut dan klorofil-a terhadap hasil tangkapan (CPUE) yaitu: $Y=-164,463+5,873 X_{1}+80,269 X_{2}$.

Uji $\dagger$ digunakan untuk mengetahui pengaruh suhu permukaan laut dan klorofil-a terhadap hasil tangkapan (CPUE) secara parsial. Hasil analisis uji $\dagger$ (Table 4.) menunjukan nilai $P$-value suhu permukaan laut sebesar 0,009>0,05, klorofil-a P-value 
$0,00048<0,05$. Ini berarti bahwa suhu permukaan laut dan klorofil-a berpengaruh terhadap hasil tangkapan (CPUE) secara parsial.

Penelitian yang dilakukan oleh Tangke et al. (2015) tentang pengaruh suhu permukaan laut dan klorofil-a terhadap hasil tangkapan tuna madidihang di perairan Halmahera selatan juga memperlihatkan bahwa kedua parameter oseanografi (suhu permukaan laut dan klorofil-a) tersebut berpengaruh secara bersama-sama maupun secara parsial terhadap hasil tangkapan tuna madidiha ng. Selain suhu permukaan laut dan klorofil-a, Maulina et al. (2019) mengemukakan bahwa selain kedua faktor oseanografi tersebut beberapa faktor lain yang diduga turut mempengaruhi hasil tangkapan yaitu kedalaman perairan, arus dan salinitas perairan.

Daerah penangkapan ikan potensial tuna madidihang dapat dilihat pada Gambar 5. Penentuan daerah penangkapan ini didasarkan pada pembobotan ketiga indikator yakni jumlah hasil tangkapan (CPUE), suhu permukaan laut optimum (SPL) dan klorofil-a.

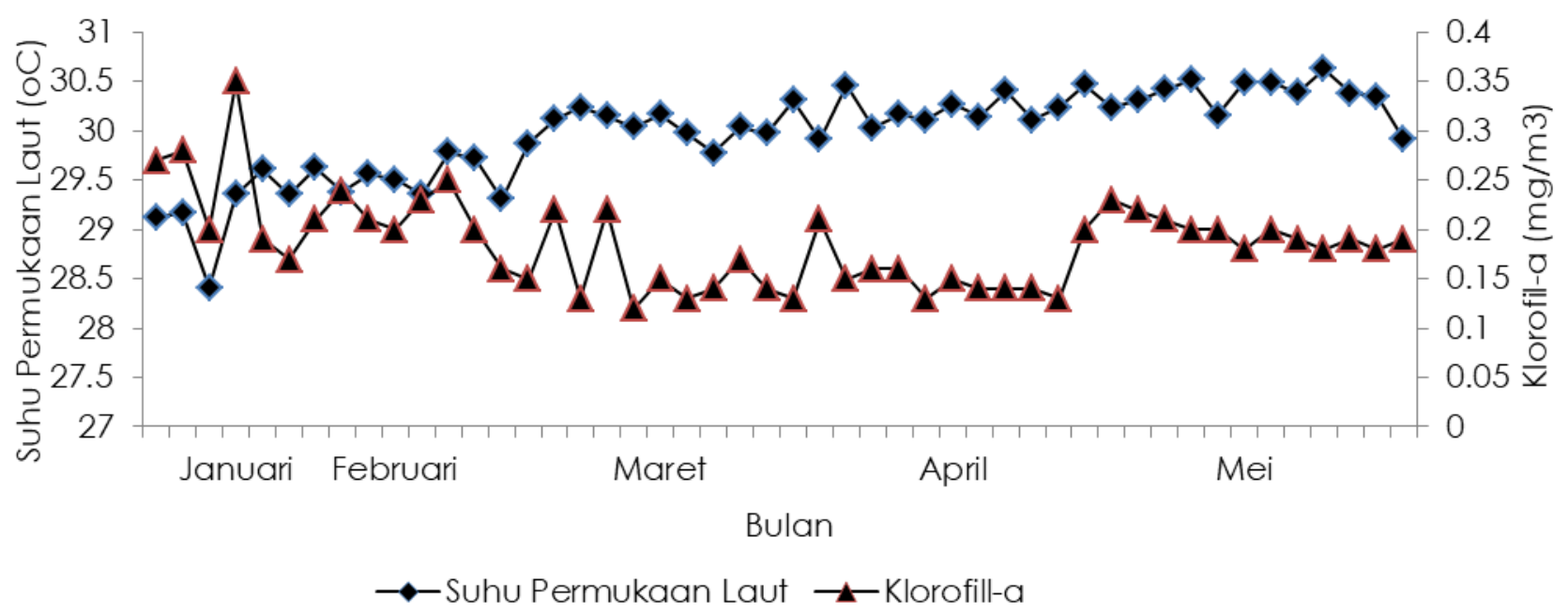

Gambar 3. Sebaran Suhu Permukaan Laut (SPL) dan Klorofil-a Pada Bulan Januari-Mei 2019

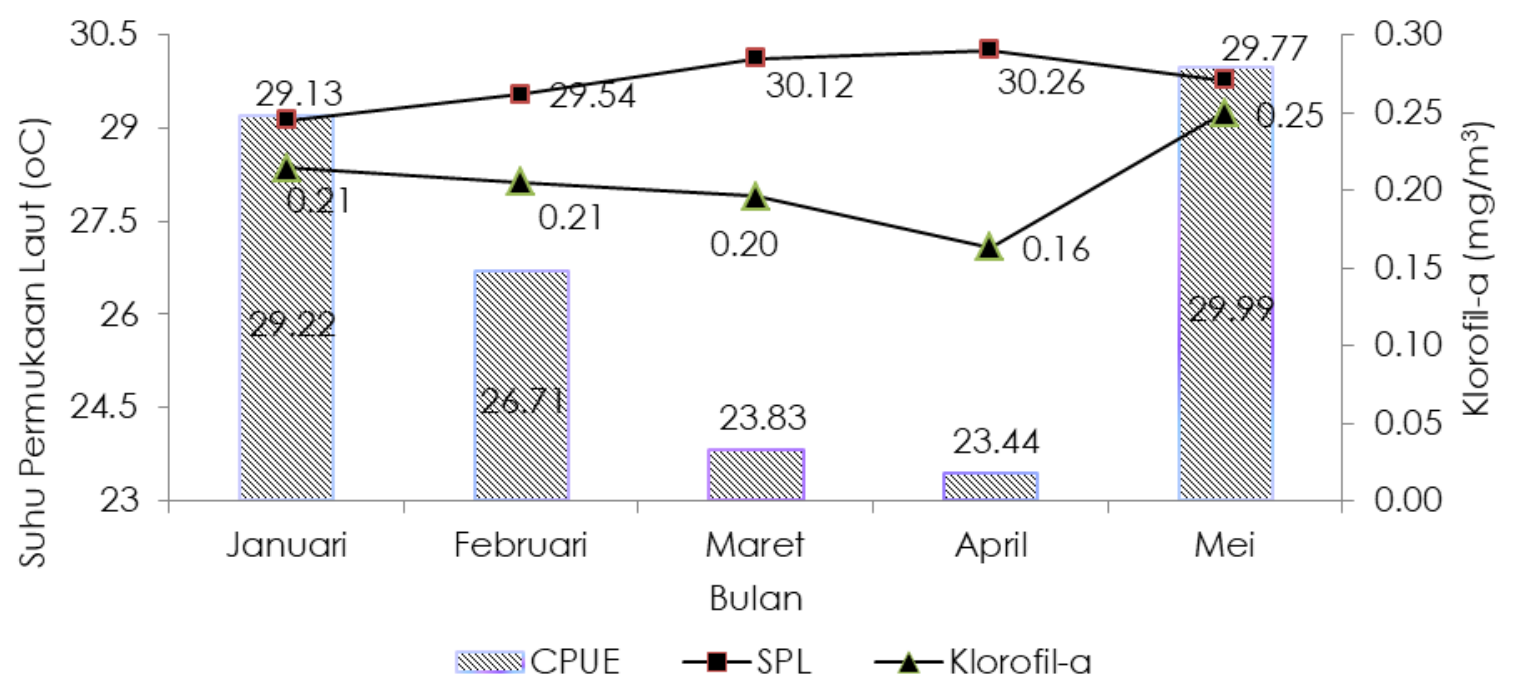

Gambar 4. Rata-rata Suhu Permukaan Laut (SPL) dan Klorofil-a bulanan Hubungannya dengan Hasil Tangkapan Pada Bulan Januari-Mei 2019 


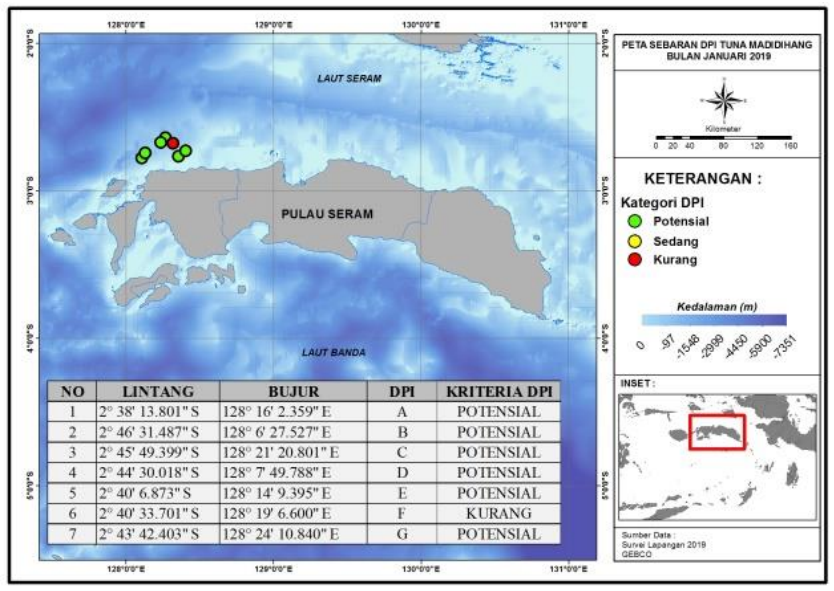

Januari

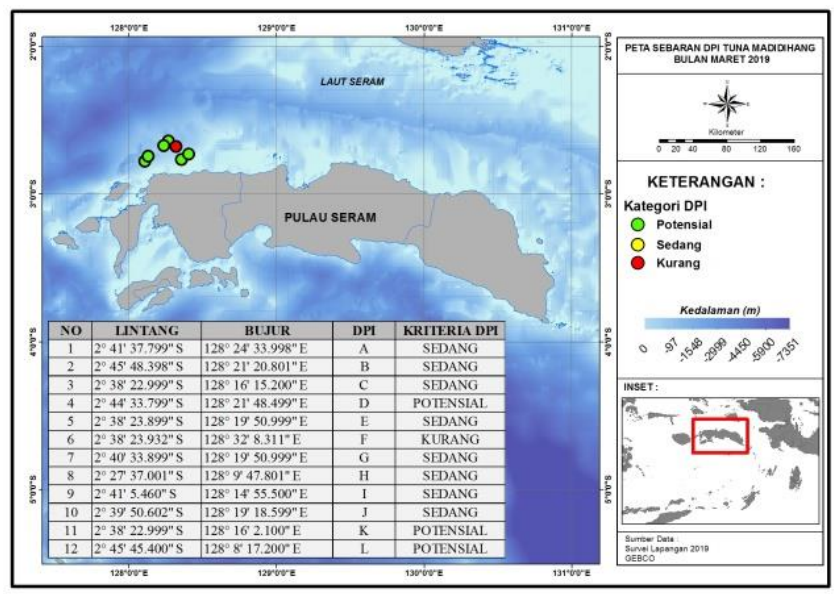

Maret

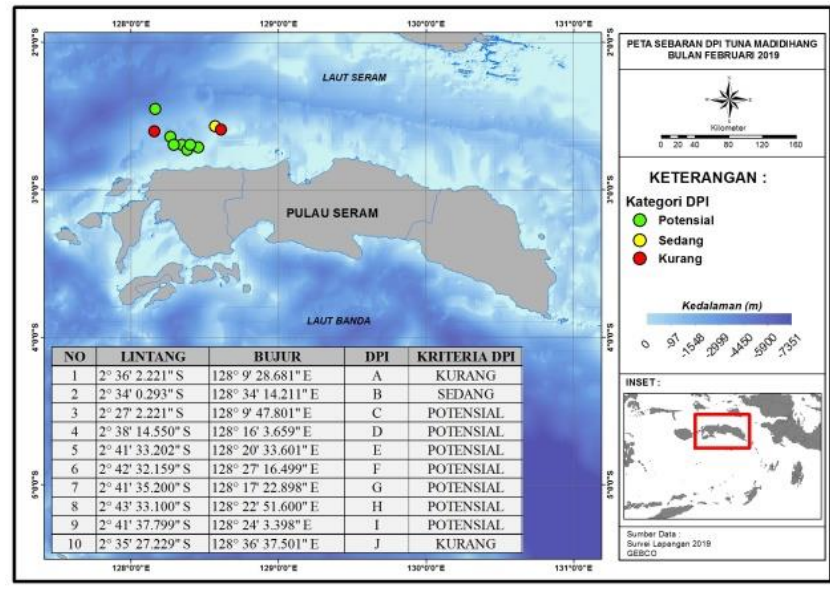

Februari

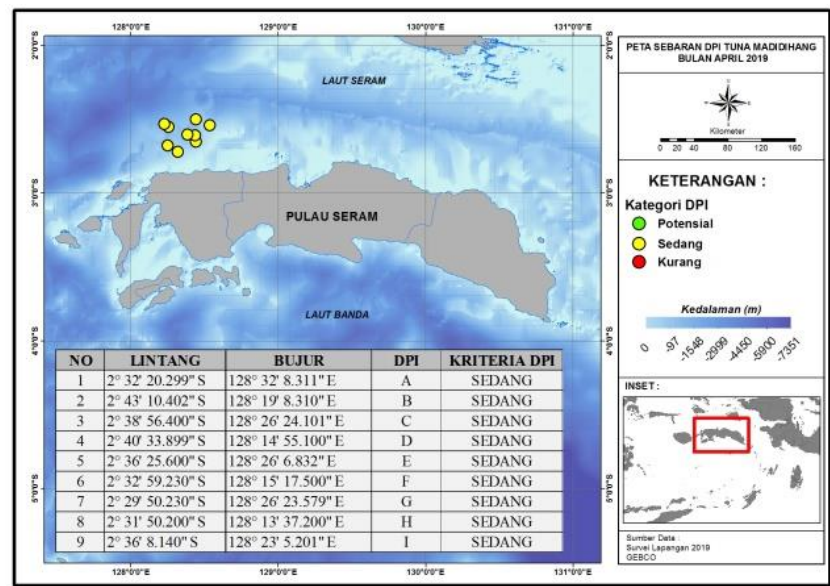

April

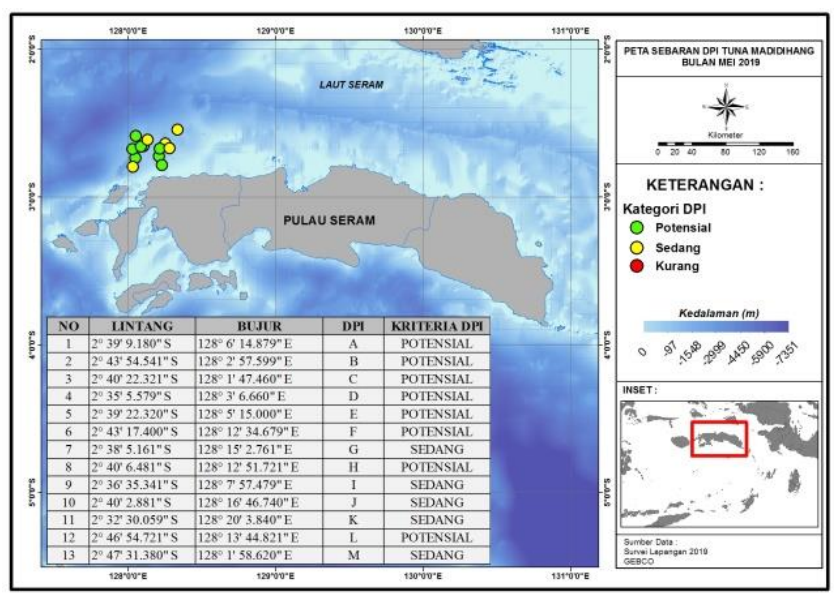

Mei

Gambar 5. Daerah Penangkapan Ikan Potensial di Laut Seram Pada Bulan Januari-Mei 2019

Hasil perhitungan DPI potensial berdasarkan pembobotan menunjukkan bahwa pada bulan Januari terdapat 2 kategori DPI potensial yaitu kategori potensial dan kurang potensial. DPI potensial yaitu: A,
B, C, D. E, G, sedangkan DPI kurang potensial yaitu F. Bulan Februari terdapat 3 kategori yaitu potensial, potensial sedang, dan kurang potensial. DPI potensial yaitu: C, D, E, F, G, H, I, DPI potensial sedang yaitu, $B$, sedangkan 
DPI kurang potensial yaitu: A dan J. Bulan Maret terdapat 3 kategori yaitu potensial, potensial sedang, dan kurang potensial. DPI potensial yaitu: $D, K$, dan $L$, Kategori DPI potensial sedang yaitu: $A, B, C, E, G, H, I, J$, DPI kurang potensial yaitu: D. Bulan April DPI seluruhnya berada dalam kategori potensial sedang yaitu: A, B, C, D, E, F, G, H, I. Bulan Mei terdapat 2 kategori DPI potensial yaitu Potensial dan potensial sedang. DPI potensial yaitu: A, B, C, D, E, F, H, L, sedangkan DPI dalam kategori sedang yaitu: $G, J, K, M$.

Hasil analisis daerah penangkapan ikan (DPI) potensial terdapat pada bulan Januari, Februari, Maret, dan Mei. Hal ini disebabkan karena ketiga kategori indikator yang dipakai untuk penentuan DPI potensial secara keseluruhan memiliki nilai bobot yang tinggi. Pada bulan April DPI berada dalam kategori potensial sedang dikarenakan hasil analisis indikator klorofil-a memiliki nilai bobot sedang bila dibandingkan dengan indikator CPUE maupun Suhu Permukaan Laut yang memiliki nilai bobot yang tinggi.

Menurut Simbolon dan Girsang (2009) bahwa konsentrasi klorofil-a tidak mempengaruhi ketersediaan ikan secara langsung di suatu wilayah perairan, namun ada jarak waktu dimana konsentrasi klorofil-a awalnya dimakan oleh organisme zooplankton atau krustasea yang masih juvenil, dan selanjutnya dimakan dalam tingkatan trofik diatasnya. Tangke, et al. (2016) mengemukakan bahwa hubungan konsentrasi klorofil-a dengan keberadaan ikan di suatu wilayah perairan merupakan hubungan mangsa pemangsa (Pray and predator) di dalam rantai makanan. Selanjutnya Loukus et al. (2003) menyatakan bahwa fitoplankton yang mengandung klorofil-a bukan merupakan makanan alamia bagi ikan tuna tetapi merupakan dasar rantai makanan bagi ikan tuna.

\section{KESIMPULAN}

Suhu permukaan laut (SPL) dan klorofil-a di Laut Seram pada bulan JanuariMei 2019 berkisar antara 28,41 ${ }^{\circ} \mathrm{C}-30,63{ }^{\circ} \mathrm{C}$ dan $0,12-0,35 \mathrm{mg} / \mathrm{m}^{3}$. Suhu permukaan laut optimum dan klorofil-a optimum penangkapan ikan tuna madidihang masing- masing berkisar antara $29-30{ }^{\circ} \mathrm{C}$ dan $0,1-0,3$ $\mathrm{mg} / \mathrm{m}^{3}$. Suhu dan klorofil berpengaruh nyata terhadap hasil tangkapan. Daerah penangkapan potensial di wilayah ini termasuk kategori daerah penangkapan potensial, potensial sedang hingga potensial rendah, dengan nilai CPUE tertinggi berdasarkan bobot hasil tangkapan terdapat pada bulan Mei, Januari dan Februari, sedangkan CPUE terendah pada bulan Maret dan April.

\section{DAFTAR PUSTAKA}

Abigail, W., Zainuri, M., Kuswardani, A.T.D. \& Pranowo, W.S., 2015, Sebaran Nutrien, Intensitas Cahaya, Klorofil-a dan Kualitas Air di Selat Badung, Bali pada Monsun Timur. J. Depik, 4(2):87-94. doi: 10.13170 /depik.4.2.2494

Allain, G.P., Lehodey, Kirby., D.S. \& Leroy, B. 2005. The Influence of the Environment on Horizontal and Vertical Bigeye Tuna Movements Investigated by Analysis of Archival tag Records and Ecosystem Model Outputs. WCPFC-SCl, 3:3p.

Bafagih, A., Hamsah, S. \& Tangke, U., 2017, Hubungan Antara Suhu Permukaan Laut dan Hasil Tangkapan Ikan Julung Di Perairan Pulau Ternate Provinsi Maluku Utara. Prosiding Seminar Nasional Kemaritiman dan Sumberdaya PulauPulau Kecil, 2(1):23-28.

Bahri, S., Simbolon, D. \& Mustaruddin. 2017, Analisis Daerah Penangkapan Ikan Madidihang (Thunnus albacares) berdasarkan Suhu Permukaan Laut dan Sebaran Klorofil-a di Perairan Provinsi Aceh. J. Teknolog. Perikan. Kelaut., 8(1):95-104. doi: 10.24319/jtpk.8.95-104

Cahya, C.N., Setyohadi, D. \& Surinati, D., 2016, Pengaruh Parameter Oseaongrafi Terhadap Distribusi Ikan. J. Oseana, $41(4): 1-14$.

Ekayana, I.M., Karang, I.W.G.A., As-syukur, A.R., Jatmiko, I., Novianto, D., 2017, Hubungan Hasil Tangkapan Ikan Tuna Selama Februari-Maret 2016 dengan Konsentrasi Klorofil-a dan SPL dari Data Penginderaan Jauh Di Perairan Selatan Jawa-Bali. J. Mar. Aqua. Sci., 3(1):19-29.

FAO. 2016, Biological Characteritics of Tuna (online). http://www.fao.org/fishery/top ic/16082/en 
Haruna, Mallawa, A. \& Zainuddin, M., 2018. Population dynamic indicator of the yellowfin tuna Thunnus albacares and its stock condition in the Banda Sea, Indonesia. Aquaculture, Aquarium, Conservation \& Legislation, 11(4):3231333.

Leavastu \& Hela, I., 1970, Fisheries Oseanography. London: Fishing News Book Ltd. 238p.

Loukus, H.O., Monfry, L.B. \& Lehodey. 2003, Potential Change in Skipjack Tuna (Katsuwonus pelamis) Habitat from a Global Warming. Fishe. Oceanograp. 12(4-5):474-482

Maulina, I.D., Triarso, I. \& Prihantoko, K.E. 2019. Daerah Potensi Penangkapan Ikan Tembang (Sardinella fimbriata) Di Laut Jawa Berdasarkan Satelit Aqua Modis. Indo. J. Fish. Sci. Technol., 15(1): 32-40.

Prayoga, I.M.S., Putra, I.D.N.N. \& Dirgayusa, I.G.N.P. 2017. Pengaruh Sebaran Konsentrasi Klorofil-a Berdasarkan Citra Satelit Terhadap Hasil Tangkapan Ikan Tongkol (Euthynnus sp) di Perairan Selat Bali. J. Mar. Aqua. Sci., 3(1):30-46.

Rochmady, R. 2015. Analisis Parameter Oseanografi Melalui Pendekatan Sistem Informasi Manajemen Berbasis Web (Sebaran Suhu Permukaan Laut, Klorofil-a dan Tinggi Permukaan Laut. J. Agribis. Perikan., 8(1):1-7.

Shabrina, N., Sunarto, N., \& Hamdani, H. 2017. Penentuan Daerah Penangkapan Ikan Tongkol Berdasarkan Pendekatan Distribusi Suhu Permukaan Laut dan Hasil Tangkapan Ikan di Perairan Utara Indramayu Jawa Barat. J. Perikan. Kelaut. 8(1):139-145.

Simbolon, D., dan Girsang, H. S. 2009. Hubungan Antara Kandungan Klorofil-a Dengan Hasil Tangkapan Tongkol di Daerah Penangkapan Ikan Perairan Pelabuhanratu. J. Peneliti. Perikan. Indo., 15(4):297-305.

Siregar, E.S.Y., Siregar, V.P. \& Agus, S.B. 2018. Analisis Darerah Penangkapan Ikan Tuna Sirip Kuning (Thunnus albacares) di Perairan Sumatra Barat Berdasarkan Model GAM. Jurnal IImu Dan Teknologi Kelautan Tropis, 10(2):501-516. doi: 10.29 244/jitkt.v10i2.21908.
Tangke, U., Karuwal, J.W., Mallawa, A., \& Zainudin, M., 2015. Sebaran Suhu Permukaan Laut dan Klorofil-a Pengaruhnya Terhadap Hasil Tangkapan Yellowfin Tuna (Thunnus albacares) Di Perairan Laut Halmahera Bagian Selatan. J. Ipteks Pemanfaatan Sumberdaya Perikan., 2(3):248-260.

Tangke, U, Karuwal, J.W., Mallawa, A. \& Zainudin, M., 2016. Analisis Parameter Oseanografi Hubungannya Dengan Hasil Tangkapan Ikan Tuna Sirip Kuning Di Perairan Maluku Utara. J. Amanisal Pemanfaatan Sumberdaya Perikan., 5(1):1-9.

Tangke, U, Karuwal, J. W., Mallawa, A., Zainudin, M. 2017. Analisis Hubungan Suhu Permukaan Laut, Salinitas, Dan Arus Dengan Hasil Tangkapan Ikan Tuna Di Perairan Bagian Barat Pulau Halmahera. J. Ipteks Pemanfaatan Sumberdaya Perikan., 3(5):368-382.

Wagiyo, K., Suman, A. \& Patria, M.P., 2015, Sebaran dan Hubungan Parameter Reproduksi Ikan Tuna Madidihang (Thunnus albacares) Dengan Suhu Dan Klorofil-a Di Laut Banda. J. Bawal, 7(3): 183-191. doi: 10.15578/bawal.7.3.2015. 183-191

Waileruny, W., \& Matruty, D.J. 2015. Analisis Finansial Usaha Penangkapan Ikan Cakalang dengan Alat Tangkap Pole and Line di Maluku Indonesia. J. Amanisal, 4(1):1-9.

Widodo, J. 1999. Aplikasi Teknologi Penginderaan Jauh untuk Perikanan di Indonesia. Prosiding Seminar Validasi Data Inderaja untuk Bidang Perikanan. Jakarta 14 April 1999. Badan Pengkajian dan Penerapan Teknologi. Jakarta.

Yunus, F., Zainuddin, M. \& Farhum, S.A., 2019. Pemetaan Potensial Penangkaan Ikan Tingkol (Euthynnus sp.) di Perairan Selat Makasar. J. Ipteks Pemanfaatan Sumberdaya Perikanan, 6(11):1-20.

Zainuddin, M., Kiyofuji, H. \& Saitoh, S., 2006, Using Multi Sensor Satellite Remote Sensing to Detect Ocean Hotpsot for Albacore Tuna (Thunnus alalunga) In The North Western North Pacific. J. Deep Sea Res., 2(53):419-431. 